\title{
Strategi Guru dalam Menstimulasi Keterampilan Motorik AUD Pada Era Pandemi Covid 19
}

\author{
Siyyella Tika Nasution', Panggung Sutapa ${ }^{2}$ \\ Pendidikan Anak Usia Dini, Universitas Negeri Yogyakarta(1) \\ Ilmu Keolahragaan, Universitas Negeri Yogyakarta (2) \\ DOI: $10.31004 /$ obsesi.v5i2.849
}

\begin{abstract}
Abstrak
Masa pandemi covid 19 telah merubah kegiatan pembelajaran di semua tingkat pendidikan termasuk PAUD dilakukan secara daring. Penelitian ini memiliki tujuan untuk mengetahui bentuk strategi yang dilakukan guru PAUD dalam menstimulasi perkembangan motorik anak usia dini di era pandemi covid 19. Penelitian ini menggunakan pendekatan deskriptif kuantitatif dengan teknik pengumpulan data menggunakan kuesioner. Jenis kuesioner yang digunakan merupakan jenis kuesioner tertutup dan kuesioner terbuka. Subjek penelitian ini terdiri dari 32 guru TK di kota Bengkulu. Penelitian ini dilakukan dengan cara menyebarkan kuesioner yang dibuat melalui Google Form dan tautannya disebar kepada guru melalui aplikasi Whatsapp. Hasil penelitian ini memberikan gambaran dan informasi mengenai bagaimana bentuk strategi yang dilakukan guru PAUD dalam menstimulasi perkembangan motorik anak di era pandemi covid 19. Selanjutnya hasil penelitian dari artikel ini dapat dijadikan salah satu referensi strategi mengajar guru dalam menstimulasi keterampilan motorik anak usia dini pada proses pembelajaran daring di era pandemi covid 19.
\end{abstract}

Kata kunci: strategi guru; Covid 19; Perkembangan Motorik

\begin{abstract}
Covid-19 pandemic has transformed learning activities at all levels of education including PAUD conducted online. This research has the aim to find out the form of strategies carried out by PAUD teachers in stimulating the motor development of early childhood in the era of the covid-19 pandemic. This study uses a quantitative descriptive approach with data collection techniques using questionnaires. The type of questionnaire used is a type of closed questionnaire and open questionnaires. The subject of this study consisted of 32 kindergarten teachers in bengkulu city. This research was conducted by disseminating questionnaires made through Google Form and the link was distributed to kindergarten teachers in Bengkulu city through whatsapp application. The results of this study provide an overview and information on how the strategy of PAUD teachers in stimulating the motor development of early childhood in the era of covid-19 pandemic. Furthermore, the results of this article can be used as one of the strategies for teaching teachers in stimulating the motor skills of early childhood in the online learning process in the era of covid-19 pandemic.
\end{abstract}

Keywords: teacher Strategy; Covid 19; Motor Development

Copyright (c) 2020 Siyyella Tika Nasution, Panggung Sutapa

$\triangle$ Corresponding author:

Email Address: siyyellatika@gmail.com (Yogyakarta, Indonesia)

Received 1 November 2020, Accepted 11 November 2020, Published 14 November 2020 


\section{PENDAHULUAN}

Istilah keterampilan motorik menggambarkan berbagai kompetensi fisik, termasuk keseimbangan dan stabilitas, gerakan terkoordinasi, dan manipulasi objek. Perbedaan antara keterampilan motorik kasar dan halus dalam artikel L. Zhang et al. (2018) yakni keterampilan motorik kasar membutuhkan koordinasi otot-otot tubuh yang lebih besar dalam keseimbangan, postur, orientasi, dan pergerakan batang dan anggota badan sedangkan keterampilan motorik halus mengintegrasikan otot-otot yang lebih kecil untuk kegiatan seperti menggambar, menulis, membaca, dan berbicara dan biasanya termasuk ketangkasan manual dan integrasi visuomotor. Koordinasi dan kontrol untuk banyak jenis dan bentuk gerakan memiliki hubungan yang kompleks antara aktivitas fisik, keterampilan motorik halus dan motorik kasar yang dirasakan pada anak usia dini (Wainwright et al., 2020).

Kegiatan yang melibatkan banyak gerakan termasuk kegiatan bermain pada anak usia dini juga merupakan faktor penting dalam pengembangan kompetensi fisik, motorik karena periode usia dini merupakan waktu optimal untuk pengembangan keterampilan motorik yang berfungsi sebagai fondasi untuk aktivitas fisik yang lebih kompleks selanjutnya. Aktivitas fisik penting untuk berbagai aspek kesehatan dan perkembangan anak anak. Tandon et al. (2020) menjelaskan bahwa aktivitas fisik pada tahun-tahun awal anak usia dini mempromosikan pengembangan keterampilan motorik kasar dan gerakan mendasar, yang merupakan fondasi untuk membentuk kepercayaan diri dan keterampilan yang diperlukan anak untuk hidup yang aktif di kemudian hari.

Keterampilan motorik halus dan motorik kasar dapat diperoleh anak secara alami melalui bermain, namun meskipun demikian banyak hal yang dapat menghambat proses alami ini terjadi tidak secara maksimal, hal ini mendukung argumen bahwa keterampilan motorik halus dan motorik kasar perlu diajarkan kepada anak dan membutuhkan tingkat instruksi yang lebih tinggi untuk menguasai gerakan kompleks yang diperlukan untuk melakukan keterampilan motorik yang lebih kompleks dengan diberikan praktik dan latihan yang terarah. Lebih lanjut menurut Temple et al. (2016) dalam kajian teori perkembangannya menyebutkan bahwa aktifitas fisik yang terarah pada masa usia dini akan membantu memaksimalkan keterampilan baik motorik halus maupun motorik kasar anak. Semakin berkualitas proses pertumbuhan dan perkembangan pada usia dini maka akan berpengaruh terhadap kualitas hidup manusia di masa mendatang. Anak-anak yang terlibat dalam aktivitas fisik, mereka akan memiliki kompetensi dasar dalam keterampilan motorik dasar, dan anak-anak belajar keterampilan dasar motorik melalui program gerakan yang dirancang dengan baik dan terencana (Robinson et al., 2012).

Pada awal tahun 2020 terjadi fenomena yang luar biasa yaitu menyebarnya virus covid 19 yang menyebabkan perubahan pada seluruh rutinitas sehari-hari termasuk rutinitas anak usia dini yang bersekolah. Hingga tanggal 1 april 2020 UNESCO mencatat sebanyak 1,5 milyar anak usia sekolah yang terdampak pandemi covid 19 di 188 negara di dunia termasuk sekitar 60 juta diantaranya ada di Indonesia. Lebih lanjut di Indonesia, berdasarkan Surat Edaran resmi Kementerian Pendidikan dan Kebudayaan No 4 tahun 2020 tentang Pelaksanaan Kebijakan Pendidikan dalam Masa Darurat Penyebaran Covid-19 di dalamnya terdapat beberapa ketentuan mengenai proses belajar di masa pandemi diantaranya aturan dilakukannya pembelajaran secara daring, aturan mengenai aktivitas dan tugas selama pembelajaran daring, dan aturan mengenai peran guru dalam memberikan umpan balik selama pembelajaran daring di rumah. Sehingga seluruh proses pembelajaran diarahkan ke pembelajaran jarak jauh yakni dilaksanakan secara daring (online). Tentu dengan adanya perubahan proses pelaksanaan pembelajaran dari yang biasanya guru dan anak bertatap muka secara langsung, akibat pandemi covid 19 yang belum kunjung membaik, guru harus menyesuaikan diri dengan proses pelaksanaan pembelajaran jarak jauh yakni secara daring yang hingga sekarang belum diketahui akan berlangsung hingga kapan sehingga guru harus siap dan menyesuaikan diri dengan kondisi pembelajaran yang tidak biasa tersebut dengan 
terus meningkatkan keterampilan terutama keterampilan dalam mengelola teknologi dalam proses pembelajaran daring.

Untuk memaksimalkan pembelajaran jarak jauh ini, guru-guru pada pendidikan anak usia dini memanfaatkan aplikasi seperti zoom meeting, WAG (Whatsapp Group), dan google meet. Seperti dalam penelitian Ismawati \& Prasetyo (2020) disebutkan bahwa salah satu aplikasi yang sering digunakan guru selama proses pembelajaran jarak jauh secara daring yaitu aplikasi zoom meeting yang mana aplikasi tersebut cukup efektif dalam mengatasi ruang jarak dan waktu dan mampu mengoptimalkan proses pembelajaran daring anak usia dini. Selain itu pembelajaran secara daring secara tidak langsung dapat mengenalkan anak kepada teknologi. Pada awal-awal proses pembelajaran daring dimulai dan dikenalkan, anak-anak sangat antusias terlebih pembelajaran menggunakan alat pendukung seperti smartphone maupun laptop yang menurut anak sangat menarik sehingga anak sangat antusias untuk ikut dalam pembelajaran (Szente, 2020).

Namun disisi lain terdapat kendala yang menyertai proses pembelajaran jarak jauh dengan sistem daring ini, seperti yang disebutkan oleh Agustin et al. (2020) dalam artikelnya yakni terdapat beberapa kendala yang dialami guru PAUD dalam mengajar di masa pandemi, salah satunya penulis menyoroti kendala yang paling tinggi persentasenya dilihat dari indikator materi pembelajaran dimana guru memiliki kendala ketika menentukan kegiatan/materi yang tepat. Berdasarkan fakta tersebut, tentu hal ini tidak dapat dibiarkan begitu saja. Karena materi pembelajaran merupakan salah satu komponen penting dalam proses pembelajaran, terdapat 6 aspek perkembangan anak usia dini yang harus distimulasi sehingga materi pembelajaran harus dapat memfasilitasi aspek perkembangan anak. Salah satu aspek perkembangan yang cukup sulit untuk dirancang materi pembelajarannya selama pembelajaran daring adalah keterampilan motorik pada anak usia dini.

Lebih lanjut dalam artikel Rasmitadila et al. (2020) juga menyebutkan salah satu kendala ataupun hambatan guru dalam melaksanakan pembelajaran secara daring di era pandemi covid 19 ini adalah strategi mengajar yang kurang menarik dan bervariatif sehingga mempengaruhi motivasi keterlibatan anak dalam proses pembelajaran, selain itu hal ini juga menyebabkan tidak optimalnya proses pembelajaran. Jika proses pembelajaran secara daring ini tidak maksimal maka juga akan mempengaruhi pengoptimalan berbagai aspek perkembangan anak usia dini yang salah satu diantaranya adalah perkembangan keterampilan motorik baik motorik halus maupun motorik kasar.

Dengan adanya berbagai kendala ataupun hambatan tersebut, perlu dilakukannya penelusuran mengenai bagaimana variasi bentuk-bentuk strategi pembelajaran yang dilakukan guru-guru PAUD selama pembelajaran daring karena guru dituntut untuk kreatif dalam menghadirkan proses pembelajaran selain itu agar meskipun pembelajaran dilaksanakan secara daring tetapi tetap dapat secara optimal memfasilitasi berbagai proses perkembangan anak, hal ini didukung oleh temuan Yao Jijun (2020) bahwa strategi dan metode pengajaran guru memiliki dampak yang signifikan pada hasil belajar anak. Sehingga penelitian ini harus dilakukan yang mana dapat mengidentifikasi variasi bentuk-bentuk strategi mengajar guru PAUD selama pembelajaran secara daring di era pandemi covid 19 untuk dapat menambah khasanah dan wawasan serta referensi yang dapat dijadikan inspirasi tentang strategi mengajar guru PAUD selama pembelajaran daring terutama dalam usaha menstimulasi perkembangan keterampilan motorik halus maupun motorik kasar anak usia dini yang membutuhkan praktek secara langsung.

Oleh karena itu tujuan dari penulisan artikel ini untuk mengetahui tentang apa saja dan bagaimana strategi guru PAUD dalam menstimulasi keterampilan motorik anak usia dini pada era pandemi covid-19. Penulis berharap hasil penelitian ini dapat membantu guru menambah kajian mengenai strategi yang dapat dilakukan guru untuk menstimulasi keterampilan motorik anak usia dini di era pandemi covid-19 dan juga dapat menjadi tambahan referensi untuk peneliti-peneliti selanjutnya. 


\section{METODOLOGI}

Pendekatan penelitian yang digunakan pada artikel ini adalah pendekatan deskriptif kuantitatif dengan menggunakan kuesioner sebagai teknik pengumpulan data. Jenis kuesioner yang digunakan adalah kuesioner terbuka dan kuesioner tertutup. Kuesioner terbuka yakni subjek penelitian diberi kebebasan untuk menjawab dan tidak diberikan pilihan jawaban sedangkan kuesioner tertutup berupa pernyataan yang mana subjek penelitian dapat menjawab dengan pilihan jawaban yang diberikan. Instrumen kuesioner terbuka berisi pertanyaan mengenai strategi yang dilakukan guru dalam proses pembelajaran untuk menstimulasi keterampilan motorik halus dan motorik kasar. Sedangkan instrumen kuesioner tertutup berisi pertanyaan mengenai pelaksanaan dan media pembelajaran daring yang dilakukan guru dalam upaya menstimulasi keterampilan motorik anak.

Data penelitian diperoleh secara online dengan menggunakan google form. Subjek dalam penelitian ini adalah guru PAUD pada gugus asparagus di kota Bengkulu yang berjumlah 32 orang. Kuesioner disebarkan dengan memanfaatkan grup para guru pada aplikasi whatsapp. Sebelum kuesioner diisi dan disebarkan kepada guru penulis meminta izin dan menjelaskan tujuan dari pengisian kuesioner tersebut sehingga guru bisa mengisi setiap butir pertanyaan sesuai dengan situasi dan kondisi guru ketika melaksanakan pembelajaran daring. Data yang diperoleh diolah dengan menggunakan docs.google.com documen yang secara langsung telah menghasilkan hasil deskripsi jawaban dari pertanyaan yang telah dijawab oleh responden penelitian. Tahapan-tahapan penelitian akan dijelaskan pada bagan 1.

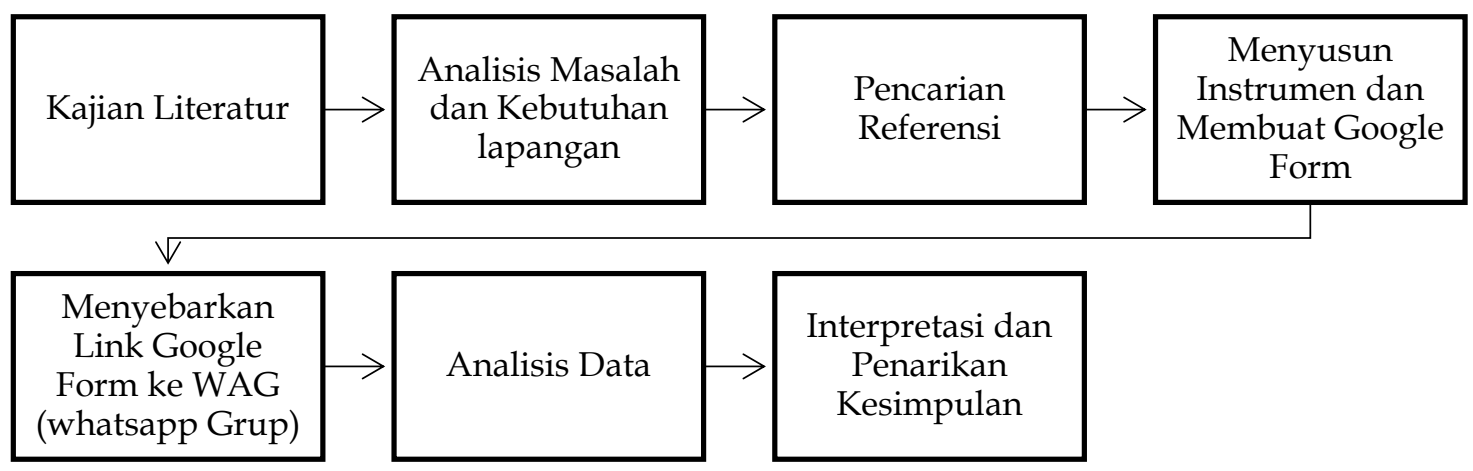

Bagan 1. Tahapan Penelitian

\section{HASIL DAN PEMBAHASAN}

Penelitian Sezici \& Akkaya (2020) mengungkapkan terdapat hubungan yang signifikan dan korelasi positif ditemukan antara keterampilan motorik kasar, motorik halus dan keterampilan perawatan diri anak-anak. Dalam penelitian tersebut ditunjukkan bahwa anak-anak perlu memperoleh keterampilan kasar dan keterampilan motorik halus untuk memperoleh keterampilan perawatan diri pada periode prasekolah. Hal ini merupakan sebuah bukti bahwa keterampilan motorik baik motorik halus maupun motorik kasar mempengaruhi perkembangan awal kecakapan hidup anak, yang mana perkembangan kecakapan hidup sangat diperlukan.

Namun, era pandemi covid 19 telah merubah sistem pembelajaran termasuk proses pembelajaran anak usia dini. Proses pembelajaran harus tetap berjalan agar anak-anak tetap dapat menerima stimulasi yang tepat dari guru sehingga guru harus melaksanakan pembelajaran dan menghadirkan proses pembelajaran yang menarik dan bermakna untuk anak meski di tengah pandemi sekalipun. Berdasarkan temuan dari (Wulandari \& Purwanta, 2020) yang menjabarkan pencapaian 6 aspek perkembangan anak usia dini selama pembelajaran daring di masa pandemi covid 19, diungkapkan sebagian besar aspek perkembangan tidak mengalami penurunan capaian perkembangan termasuk salah satunya yaitu fisik motorik yang capaian perkembangannya tetap berkembang sesuai tahap 
perkembangan masing-masing anak. Hal ini menunjukkan bahwa pencapaian perkembangan yang tidak menurun tersebut tentunya dipengaruhi oleh faktor-faktor pendukung yang salah satunya adalah strategi mengajar guru selama pembelajaran daring yang selanjutnya akan dibahas pada temuan penelitian pada artikel ini.

Temuan Brian \& Taunton (2018) juga menjelaskan bahwa strategi pembelajaran dan pemilihan variasi stimulasi yang tepat dapat membantu mengatasi keterlambatan capaian perkembangan anak terutama perkembangan motorik baik motorik halus dan motorik kasar. Sehingga strategi pembelajaran yang tepat memiliki pengaruh terhadap proses berbagai aspek perkembangan anak, terutama selama pembelajaran daring di masa pandemi covid 19 ini sangat memerlukan strategi yang tepat dan tentunya variatif agar proses pembelajaran daring tetap memiliki dampak positif yang sama dengan pembelajaran tatap muka. Oleh karena itu akan dibahas hasil dari penelitian ini yang mana akan menjabarkan bagaimana bentuk-bentuk strategi pembelajaran daring dalam menstimulasi perkembangan keterampilan motorik halus dan motorik kasar.

Berdasarkan hasil olah data kuesioner tertutup yang disajikan pada diagram 1, 2, 3 dan diagram 4. Pada diagram 1 dapat dilihat $6,3 \%$ atau 2 orang guru menjawab tidak, $28,1 \%$ atau 9 orang guru menjawab kadang-kadang dan 65,6\% atau 21 orang guru menjawab ya melaksanakan pembelajaran secara daring (online) selama pandemi covid-19. Hal ini menunjukkan bahwa sebagian besar guru PAUD pada gugus asparagus di Kota Bengkulu sudah melaksanakan pembelajaran secara daring (online) walaupun masih terdapat guru yang kadang-kadang melaksanakan dan sedikit sekali yang tidak melaksanakan pembelajaran secara daring (online). Bagaimanapun juga perkembangan teknologi yang pesat telah membuat pendidikan jarak jauh menjadi mudah, oleh karenanya kesempatan guru dalam melaksanakan pembelajaran daring menjadi lebih besar dan diharapkan pembelajaran dapat tetap efektif dan optimal meskipun tidak dilaksanakan secara tatap muka sehingga tujuan pendidikan dalam memfasilitasi proses perkembangan anak dapat terwujud (Dhawan, 2020).

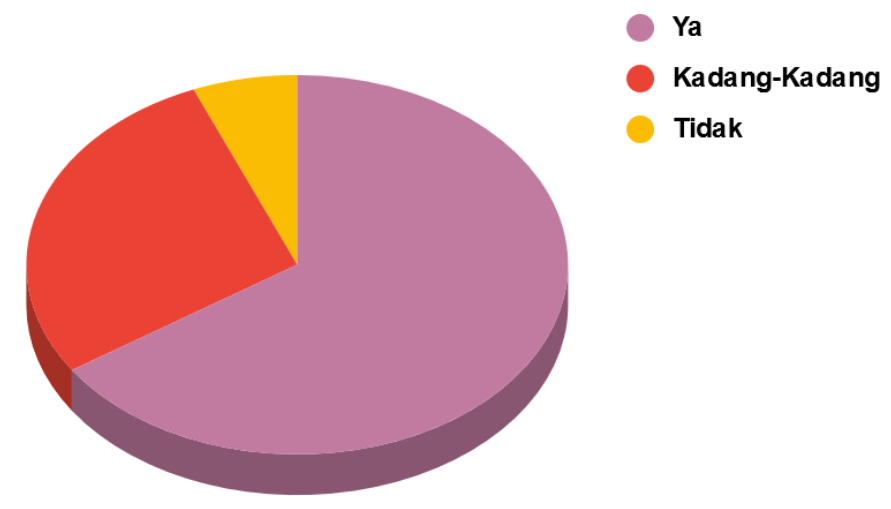

\section{Diagram 1. Guru Melaksanakan Pembelajaran Daring (Online)}

Selama pelaksanaan pembelajaran jarak jauh dilakukan, sudah banyak sekali media yang mampu mengakomodasi kebutuhan pembelajaran secara online. Oleh karenanya guru harus mampu menyesuaikan diri dengan teknologi yang berkembang pesat tersebut, karena jika perkembangan teknologi yang ada tidak dibarengi dengan keterampilan yang cukup dalam mengelola pembelajaran dengan teknologi yang ada maka proses pembelajaran secara daring tidak akan optimal. Sikap dan keterampilan guru anak usia dini dalam penggunaan teknologi juga mempengaruhi motivasi dan pembelajaran anak, terlebih untuk keterampilan motorik pada anak usia dini sangat memerlukan proses pembelajaran yang aktif agar perkembangannya dapat maksimal (Kim, 2020). 


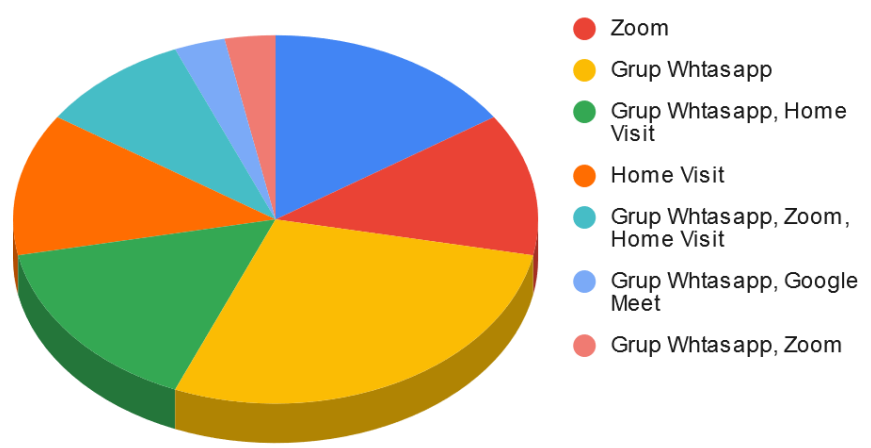

\section{Diagram 2. Media Yang Digunakan Guru Pada Pembelajaran Daring}

Pada diagram 2 dapat dilihat guru PAUD sudah menggunakan media yang dapat mengakomodasi proses pembelajaran daring namun beberapa guru juga melakukan home visit sebagai alternatif pelaksanaan kegiatan belajar agar dapat melihat secara langsung perkembangan terutama perkembangan motorik anak. 15,6\% hanya menggunakan google meet, $12,5 \%$ guru hanya menggunakan zoom meeting, dan $28,1 \%$ guru hanya menggunakan grup whatsapp, 15,6 \% guru menggunakan grup whatsapp dan melakukan home visit, 12,5\% guru hanya melakukan home visit, 9,4\% guru menggunakan grup whatsapp, zoom meeting dan home visit, 3,1\% guru menggunakan grup whatsapp dan google meet, 3,1\% guru menggunakan media grup whatsapp dan zoom meeting sebagai media pembelajaran daring. Artinya guru PAUD sudah mampu menyesuaikan pembelajaran secara daring dengan mengkombinasi media belajar yang digunakan ditambah dengan melakukan home visit dapat menambah efektifitas proses pembelajaran jarak jauh. Selain itu dengan memanfaatkan berbagai media dan teknologi secara tidak langsung mengenalkan, dan membantu anak mempelajari manfaat serta mengamati beragam teknologi (Kim, 2020).

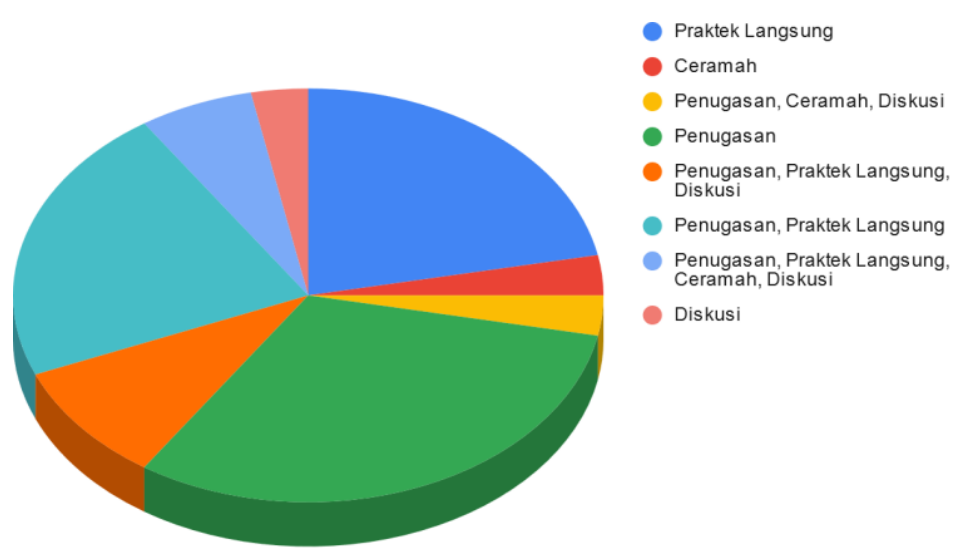

\section{Diagram 3. Metode Pembelajaran Daring Untuk Menstimulasi Keterampilan Motorik Halus}

Pada diagram 3 dapat dilihat guru menggunakan berbagai macam metode dalam melaksanakan pembelajaran daring terutama untuk menstimulasi keterampilan motorik halus. $21,9 \%$ guru hanya menggunakan metode praktek langsung, 3,1\% guru hanya menggunakan metode ceramah, 3,1\% guru menggunakan metode penugasan, ceramah dan diskusi, 31,3\% guru hanya menggunakan metode penugasan, 9,4\% guru menggunakan metode penugasan, praktek langsung dan diskusi, 21,9\% guru menggunakan metode penugasan dan praktek langsung, 6,3\% guru menggunakan metode penugasan, praktek langsung, ceramah dan diskusi, serta 3,1\% guru menggunakan metode diskusi. 


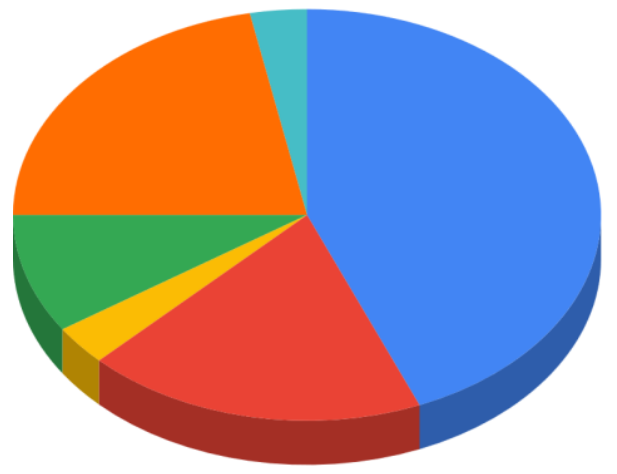

$$
\begin{aligned}
& \text { Paraktek Langsung } \\
& \text { Penugasan } \\
& \text { Penugasan, Ceramah, Diskusi } \\
& \text { Penugasan, Paraktek Langsung, } \\
& \text { Diskusi } \\
& \text { Penugasan, Paraktek Langsung } \\
& \text { Ceramah }
\end{aligned}
$$

\section{Diagram 4. Metode Pembelajaran Daring Untuk Menstimulasi Keterampilan Motorik Kasar}

Pada diagram 4 dapat dilihat guru juga mengkombinasi metode pembelajaran daring dalam menstimulasi perkembangan motorik kasar anak. 43,8 \% guru menggunakan metode praktek langsung, 18,8 \% guru menggunakan metode penugasan, 3,1 \% guru menggunakan metode penugasan, ceramah, dan diskusi, 9,4 \% guru menggunakan metode penugasan, praktek langsung dan diskusi, 21,9\% guru menggunakan metode penugasan dan praktek langsung, 3,1\% guru hanya menggunakan metode ceramah.

Berdasarkan diagaram 3 dan 4 dapat diketahui bahwa guru sudah mengadakan inovasi sedemikian rupa untuk memperlancar proses pembelajaran secara daring. Berbagai metode digunakan dan dikombinasi agar memaksimalkan usaha menstimulasi keterampilan motorik halus dan motorik kasar. Hal ini sejalan dengan berbagai penelitian akademik yang telah mengungkapkan bahwa pertumbuhan kognitif dan fisik yang luar biasa pada anak usia dini, tunduk pada pengaruh lingkungan anak (Sigmundsson \& Haga, 2016). Oleh karenanya dengan dukungan stimulasi terutama guru diharapkan mampu memaksimalkan perkembangan keterampilan fisik motorik anak di tengah pandemi covid 19 sekalipun.

Selanjutnya berdasarkan hasil olah data kuesioner terbuka diperoleh jawaban guru yang bervariasi mengenai strategi yang dilakukan dalam menstimulasi keterampilan motorik halus dan motorik kasar, berikut ini adalah bentuk strategi yang yang sudah di klasifikasikan dengan bentuk metode yang digunakan guru disajikan pada tabel 1 :

Tabel 1. Strategi guru dalam menstimulasi keterampilan motorik halus dan kasar selama pembelajaran daring dengan metode ceramah dan diskusi

\begin{tabular}{lll}
\hline No. & $\begin{array}{l}\text { Strategi guru dalam menstimulasi } \\
\text { keterampilan motorik halus selama } \\
\text { pembelajaran daring }\end{array}$ & $\begin{array}{l}\text { Strategi guru dalam menstimulasi } \\
\text { keterampilan motorik kasar selama } \\
\text { pembelajaran daring }\end{array}$ \\
\hline 1 & $\begin{array}{l}\text { Guru memberikan contoh terlebih dahulu } \\
\text { dengan menampilkan/ memberikan video } \\
\text { pada WA orang tua. }\end{array}$ & $\begin{array}{l}\text { Guru memberikan contoh terlebih dahulu } \\
\text { dengan menampilkan/ memberikan video } \\
\text { pada WA orang tua. }\end{array}$ \\
\hline 2 & $\begin{array}{l}\text { Menjelaskan tentang kegiatan belajar yang } \\
\text { akan dilakukan di group whatsapp setelah itu } \\
\text { guru memberikan tugas kepada anak dan } \\
\text { anak langsung mengerjakan kegiatan } \\
\text { tersebut. }\end{array}$ & $\begin{array}{l}\text { Menjelaskan tentang kegiatan belajar yang } \\
\text { itu guru memberikan tugas kepada anak } \\
\text { dan anak langsung mengerjakan kegiatan } \\
\text { tersebut }\end{array}$ \\
\hline 3 & $\begin{array}{l}\text { Menggunakan grup whatsapp dan menjelas } \\
\text { kan kepada anak cara membuat sebuah karya } \\
\text { seperti kolase, menempel dll dengan bantuan } \\
\text { org tua }\end{array}$ & $\begin{array}{l}\text { Memberikan arahan kepada orang tua } \\
\text { untuk membantu dan mendukung anak } \\
\text { melakukan kegiatan fisik ringan selama di } \\
\text { rumah }\end{array}$ \\
\hline $\begin{array}{l}\text { Guru memberikan contoh terlebih dahulu } \\
\text { gerakan }{ }^{2} \text { dengan menampilkan/ memberikan } \\
\text { video pada WA orang tua. }\end{array}$ & $\begin{array}{l}\text { Guru memberikan contoh terlebih dahulu } \\
\text { gerakan }{ }^{2} \text { dengan } \\
\text { memberikan video pada WA orang tua. }\end{array}$ \\
\hline
\end{tabular}


Berdasarkan tabel 1 dapat dilihat bahwa strategi pembelajaran yang dilakukan guru sangat bervariasi. Strategi guru dalam menstimulasi keterampilan motorik halus maupun kasar dengan metode ceramah dan diskusi lebih memaksimalkan pendekatan dan pemberian arahan kepada orang tua untuk mendampingi anak dalam pelaksanaan proses pembelajaran dengan memanfaatkan WAG (whatsapp grup) sebagai medianya. Dalam hal ini memang peran orang tua juga sangat diperlukan karena selama proses pembelajaran daring orang tua jauh lebih instens mendampingi anak, selaras dengan Gu et al. (2019) yang menjelaskan pentingnya dorongan dan keterlibatan orang tua dalam proses pembelajaran yang diadakan guru, terutama fisik motorik karena orang tua sepenuhnya lebih memahami kondisi dan kemampuan fisik motorik anak terutama selama dirumah.

Tabel 2. Strategi guru dalam menstimulasi keterampilan motorik halus dan kasar selama pembelajaran daring dengan metode praktek langsung

\begin{tabular}{|c|c|c|}
\hline No & $\begin{array}{l}\text { Strategi guru dalam menstimulasi } \\
\text { keterampilan motorik halus selama } \\
\text { pembelajaran daring }\end{array}$ & $\begin{array}{l}\text { Strategi guru dalam menstimulasi } \\
\text { keterampilan motorik kasar selama } \\
\text { pembelajaran daring }\end{array}$ \\
\hline 1 & $\begin{array}{l}\text { Menggerakkan jari untuk mengambil benda, } \\
\text { menggambar, meniru garis }\end{array}$ & $\begin{array}{l}\text { Praktek langsung dengan melakukan } \\
\text { kegiatan seperti senam melalui gerak dan } \\
\text { lagu }\end{array}$ \\
\hline 2 & $\begin{array}{l}\text { Mengajak anak melakukan kegiatan } \\
\text { menjimpit, meremas benda benda di rumah } \\
\text { yg dapat menstimulasi motorik halus anak }\end{array}$ & $\begin{array}{l}\text { Mengarahkan anak bergerak sesuai instruksi } \\
\text { untuk bergerak sesuai musik }\end{array}$ \\
\hline 3 & $\begin{array}{l}\text { Memberikan contoh kegiatan meronce, atau } \\
\text { menggunting pola yang kemudia anak harus } \\
\text { mempraktekkan kegiatan yang sama }\end{array}$ & $\begin{array}{l}\text { Salah satu strateginya guru mengajak anak } \\
\text { menyiram tanaman rumahnya }\end{array}$ \\
\hline 4 & $\begin{array}{l}\text { Setiap sebelum memulai belajar mengajak } \\
\text { anak } \\
\text { untuk meregangkan jari-jari dengan diiringi } \\
\text { lagu yang seru }\end{array}$ & $\begin{array}{l}\text { Menyiapkan gerakan tari atau gerakan yang } \\
\text { disesuaikan dengan tema dan kemudian } \\
\text { mengajak anak untuk mempraktekkan } \\
\text { gerakan-gerakan tsb sesuai urutan }\end{array}$ \\
\hline 5 & $\begin{array}{l}\text { Bersama-sama mempraktekkan membuat } \\
\text { karya seperti melipat kertas menjadi bentuk } \\
\text { binatang atau benda lain yang disesuaikan } \\
\text { dengan tema pembelajaran }\end{array}$ & $\begin{array}{l}\text { Mengajak anak bernyanyi } r \\
\text { menggerakkan anggota tubuh } \\
\text { diiringi lagu }\end{array}$ \\
\hline 6 & $\begin{array}{l}\text { Dengan memberikan kegiatan pembelajaran } \\
\text { yang kreatif dan menarik seperti mewarnai } \\
\text { dengan tekhnik airbrush, mengecap dgn } \\
\text { Cotton buds, menempel dgn daun kering dan } \\
\text { sebagainya }\end{array}$ & $\begin{array}{l}\text { Melakukan gerakan-gerakan seperti senam, } \\
\text { bertepuk dan lain-lain melalui video }\end{array}$ \\
\hline 7 & $\begin{array}{l}\text { Mengirim video kegiatan main yg } \\
\text { merangsang } \\
\text { motorik halus seperti bermain ubleg,meremas } \\
\text { koran, mencetak pasir dan anak2 di.minta } \\
\text { mempraktekkan dirumah kemudian } \\
\text { mengirimkan video kegiatan ke guru }\end{array}$ & $\begin{array}{l}\text { Memberikan arahan dan contoh pada anak } \\
\text { untuk berjalan diatas papan titian yang setiap } \\
\text { hari tingkat kesulitan dari papan titian } \\
\text { ditambah }\end{array}$ \\
\hline 8 & $\begin{array}{l}\text { Mengajari anak cara melipat kertas menjadi } 2 \\
\text { atau } 3 \text { lipatan }\end{array}$ & $\begin{array}{l}\text { Memberikan arahan dan contoh pada anak } \\
\text { untuk berjalan jinjit }\end{array}$ \\
\hline 9 & $\begin{array}{l}\text { Menayangkan video guru ketika melakukan } \\
\text { olahraga jari, untuk kemudia anak menirukan }\end{array}$ & $\begin{array}{l}\text { Mengajak anak untuk mempraktekkan } \\
\text { gerakan-gerakan sederhana pada saat } \\
\text { mengerjakan pekerjaan rumah seperti } \\
\text { menyapu, mengepel, dan lain-lain }\end{array}$ \\
\hline
\end{tabular}

Berdasarkan tabel 2, terlihat strategi yang dilakukan, langsung diarahkan oleh guru melalui video conference dengan memanfaatkan aplikasi seperti yang talah disebutkan sebelumnya yakni zoom meeting, google meet, bahkan dengan home visit. Strategi guru dalam 
menstimulasi keterampilan motorik halus mapun kasar anak dengan metode praktek langsung lebih banyak menampilkan kegiatan membuat pra karya, melibatkan musik dan lagu, dan mempraktekkan gerakan-gerakan sederhana yang sering dilakukan sehari-hari. Sejalan dengan Suggate et al. (2017) dalam penelitiannya yang menyebutkan aktivitas bermain yang dilakukan anak sehari-hari secara tidak langsung dapat mempengaruhi perkembangan keterampilan motoriknya, apalagi jika aktivitas sehari-hari tersebut benar-benar diarahkan dengan baik, maka akan dapat memberikan efek positif yang lebih terarah bagi perkembangan keterampilan fisik motorik anak. Kegiatan fisik memicu imajinasi anak-anak, yang mengarah pada eksplorasi dan stimulasi dalam lingkungan mereka, yang mendukung pengembangan keterampilan motorik, aktivitas fisik yang terdiri dari perilaku motorik kotor dan halus dapat memperkuat konteks keterampilan motorik anak dengan kuat (Akamoglu et al., 2019).

Tabel 3. Strategi guru dalam menstimulasi keterampilan motorik halus dan kasar selama pembelajaran daring dengan metode penugasan

\begin{tabular}{|c|c|c|}
\hline No. & $\begin{array}{l}\text { Strategi guru dalam menstimulasi } \\
\text { keterampilan motorik halus selama } \\
\text { pembelajaran daring }\end{array}$ & $\begin{array}{l}\text { Strategi guru dalam menstimulasi } \\
\text { keterampilan motorik kasar selama } \\
\text { pembelajaran daring }\end{array}$ \\
\hline 1 & $\begin{array}{l}\text { Dengan memberi tugas mingguan, anak dapat } \\
\text { mengembangkan motorik halusnya melalui } \\
\text { menulis dan mewarnai di buku pembelajaran }\end{array}$ & $\begin{array}{l}\text { Menugaskan anak untuk setiap hari merekam } \\
\text { video ketika anak berolahraga ringan selama } \\
\text { di rumah }\end{array}$ \\
\hline 2 & $\begin{array}{l}\text { Memberikan tugas seperti membuat kolase, } \\
\text { menggunting pola, membuat prakarya yang } \\
\text { proses pembuatan tugas tersebut divideokan } \\
\text { oleh orang tua }\end{array}$ & $\begin{array}{l}\text { Menugaskan anak untuk setiap hari merekam } \\
\text { video ketika anak berolahraga ringan selama } \\
\text { di rumah }\end{array}$ \\
\hline 3 & $\begin{array}{l}\text { Menjelaskan dan memberikan contoh dulu } \\
\text { sesuai tema melalui buku, video dan } \\
\text { memberikan bahan ajar setiap } 1 \text { minggu sekali } \\
\text { serta memberikan bahan utk tindak lanjut } \\
\text { orang tua anak di rumah, sehingga anak2 } \\
\text { dapat mengikuti dan mengerjakannya di } \\
\text { rumah. Misal: menulis, menggambar dll. }\end{array}$ & $\begin{array}{l}\text { Menugaskan anak untuk merekam video } \\
\text { ketika anak sedang senam dengan bantuan } \\
\text { orang tua }\end{array}$ \\
\hline 4 & $\begin{array}{l}\text { Menugaskan anak setiap minggu nya untuk } \\
\text { memberikan video gerakan-gerakan } \\
\text { sederhana pada saat mengerjakan pekerjaan } \\
\text { rumah sperti mencuci piring, membersihkan } \\
\text { kaca dan lain-lain }\end{array}$ & $\begin{array}{l}\text { Merekam kegiatan mingguan yang ada } \\
\text { ditema perminggu seperti melompat }\end{array}$ \\
\hline 5 & $\begin{array}{l}\text { Memberikan penugasan setiap minggunya } \\
\text { untuk anak menggambar bentuk-bentuk } \\
\text { geometri }\end{array}$ & $\begin{array}{l}\text { Mengirim video kegiatan main yg } \\
\text { merangsang motorik kasar seperti bermain } \\
\text { lompat kodok,membantu ortu } \\
\text { menyapu,senam fantasi, dan anak di minta } \\
\text { mempraktekkan dirumah kemudian } \\
\text { mengirimkan video kegiatan ke guru }\end{array}$ \\
\hline 6 & $\begin{array}{l}\text { Memberikan penugasan setiap minggunya } \\
\text { untuk anak menggambar kegiatan sehari-hari } \\
\text { yang dilakukan sesuai imajinasinya }\end{array}$ & $\begin{array}{l}\text { Menugaskan untuk melakukan gerakan } \\
\text { seperti belajar gerakan sholat dan wudhu }\end{array}$ \\
\hline 7 & $\begin{array}{l}\text { Memberikan tutorial video saat guru } \\
\text { membuat plastisin untuk kemudian } \\
\text { dipraktekkan oleh anak dan direkam sebagai } \\
\text { penugasan }\end{array}$ & $\begin{array}{l}\text { Mengajak anak melakukan kegiatan lari pagi } \\
\text { untuk menstimulasi motorik kasar anak }\end{array}$ \\
\hline 8 & $\begin{array}{l}\text { Memberikan kesempatan pada anak untuk } \\
\text { menciptakan gerakan tari sesuai imajinasinya } \\
\text { sendiri yang diiringi lagu dan direkam } \\
\text { sebagai penugasan. }\end{array}$ & $\begin{array}{l}\text { Guru membuat video pembelajaran dan } \\
\text { memberi contoh keterampilan motorik kasar } \\
\text { sesuai rpph, anak diminta menirukan dan } \\
\text { mengirimkan foto/ vidionya }\end{array}$ \\
\hline
\end{tabular}


Pada tabel 3 terlihat, strategi yang dilakukan guru lebih fokus pada penugasan, penugasan yang dimaksud hampir sama dengan metode praktek langsung namun pada beberapa poin guru memberikan kesempatan pada anak untuk mempraktekkan kegiatan menirukan gerakan, membuat prakarya, menciptakan gerakan tari yang diringi oleh musik dan lagu yang disukai anak dengan imajinasi mereka sendiri kemudian direkam menjadi video dan dikirimkan pada guru. Aktivitas fisik yang benar-benar langsung dipraktekkan akan membekas pada proses perkembangan anak. Apalagi aktivitas fisik dan pengalaman gerakan selama usia prasekolah membantu anak-anak meningkatkan keterampilan motoriknya. Selain itu peningkatan kontrol tangan dan jari menyebabkan peningkatan keterampilan motorik halus (C. Zhang \& Quinn, 2018). Oleh karena itu, melalui program olahraga, anak-anak terus mengintegrasikan keterampilan motorik yang diperoleh sebelumnya ke dalam sistem aksi yang lebih kompleks, oleh karenanya stimulasi yang tepat dapat membantu proses natural tersebut. Gallotta et al. (2018) menjelaskan bahwa aktivitas fisik dapat secara positif mempengaruhi pertumbuhan dan perkembangan anak-anak, berkontribusi pada keseimbangan perkembangan kognitif, emosional, dan sosial dan terutama keterampilan fisik.

Berdasarkan tabel 1, 2, dan 3 dapat dipahami bahwa bentuk strategi yang dilakukan guru dalam menstimulasi aspek perkembangan anak terutama perkembangan keterampilan motorik baik motorik halus dan motorik kasar anak sangat lah bervariatif. Terlebih pada proses pembelajaran daring ini guru dituntut untuk lebih kreatif dalam menghadirkan pengalaman belajar yang tetap bermakna, apalagi keterampilan motorik tidak cukup hanya mengandalkan metode ceramah dan diskusi. Keterampilan motorik juga harus didukung dengan lebih banyak mempraktekkan kegiatan-kegiatan secara langsung. Hal ini didukung oleh Clark \& Metcalfe (2002) yang menyatakan bahwa keterampilan motorik tidak hanya datang sebagai hadiah ulang tahun mereka harus dipelihara, dipromosikan, dan dipraktikkan. Semakin banyak aktifitas fisik terarah yang dilakukan dan dipraktikkan secara langsung anak maka akan sangat membantu optimalnya proses perkembangan motorik. Lebih lanjut, salah satu keterampilan motorik yaitu keterampilan pengendalian objek atau disebut dengan keterampilan manipulatif seperti menangkap, menendang dan melempar dapat membentuk fondasi untuk keterampilan motorik yang lebih baik pada anak usia dini di masa yang akan datang (Reska, 2015). Oleh karenanya perkembangan keterampilan motorik pada anak usia dini harus distimulasi sedemikian rupa agar dapat berkembang maksimal sesuai dengan tahap perkembangan.

\section{SIMPULAN}

Hasil penelitian menunjukkan guru sudah melaksanakan pembelajaran daring dengan memanfaatkan teknologi yakni menggunakan bantuan media aplikasi untuk dapat memaksimalkan stimulasi keterampilam motorik baik motorik halus maupun motorik kasar. Metode yang digunakan juga sudah bervariasi dan dikombinasikan sesuai dengan kebutuhan seperti ceramah dan diskusi, penugasan dan praktek langsung. Strategi yang dilakukan juga cukup banyak, seperti melibatkan orang tua dirumah untuk memberikan arahan kegiatan dalam bentuk video yang sudah disiapkan oleh guru sendiri, memanfaatkan gerakan-gerakan kegiatan sehari-hari, memanfaatkan barang-barang yang ada disekitar anak, menggunakan musik dan lagu, yang mana anak diberi kesempatan untuk mempraktekkan langsung gerakan-gerakan yang sudah diarahkan oleh guru.

\section{UCAPAN TERIMA KASIH}

Terimakasih kepada guru-guru PAUD gugus asparagus Kota Bengkulu yang sudah bersedia menjadi responden dan membantu kelancaran penelitian ini. Serta terimakasih kepada Bapak Dr. Drs. Panggung Sutapa, M.S. selaku dosen pembimbing penulisan artikel ini. 


\section{DAFTAR PUSTAKA}

Agustin, M., Puspita, R. D., Nurinten, D., \& Nafiqoh, H. (2020). Tipikal Kendala Guru PAUD dalam Mengajar pada Masa Pandemi Covid 19 dan Implikasinya. Jurnal Obsesi : Jurnal Pendidikan Anak Usia Dini, 5(1), 334. https:/ / doi.org/10.31004/obsesi.v5i1.598

Akamoglu, Y., Ostrosky, M. M., Cheung, W. C., Yang, H. W., Favazza, P. C., Stalega, M. V., \& Aronson-Ensign, K. (2019). Move Together, Communicate Together: Supporting Preschoolers' Communication Skills Through Physical Activities. Early Childhood Education Journal, 47(6), 677-685. https://doi.org/10.1007/s10643-019-00957-1

Brian, A., \& Taunton, S. (2018). Effectiveness of motor skill intervention varies based on implementation strategy. Physical Education and Sport Pedagogy, 23(2), 222-233. https:// doi.org/10.1080/17408989.2017.1413709

Clark, J. E., \& Metcalfe, J. S. (2002). the Mountain of Motor Development: a Metaphor. Motor Development: Research and Reviews, 2(January 2002), 163-190.

Dhawan, S. (2020). Online Learning: A Panacea in the Time of COVID-19 Crisis. Journal of Educational Technology Systems, 49(1), 5-22. https:/ / doi.org/10.1177/0047239520934018

Gallotta, M. C., Baldari, C., \& Guidetti, L. (2018). Motor proficiency and physical activity in preschool girls: a preliminary study. Early Child Development and Care, 188(10), 13811391. https:// doi.org/10.1080/03004430.2016.1261337

Gu, X., Chen, S., \& Zhang, X. (2019). Physical literacy at the start line: Young children's motor competence, fitness, physical activity, and fitness knowledge. Journal of Teaching in Physical Education, 38(2), 146-154. https:/ / doi.org/10.1123/jtpe.2018-0069

Ismawati, D., \& Prasetyo, I. (2020). Efektivitas Pembelajaran Menggunakan Video Zoom Cloud Meeting pada Anak Usia Dini Era Pandemi Covid-19. Jurnal Obsesi : Jurnal Pendidikan Anak Usia Dini, 5(1), 665. https:/ / doi.org/10.31004/obsesi.v5i1.671

Kim, J. (2020). Learning and Teaching Online During Covid-19: Experiences of Student Teachers in an Early Childhood Education Practicum. International Journal of Early Childhood, 52(2), 145-158. https://doi.org/10.1007/s13158-020-00272-6

Rasmitadila, Aliyyah, R. R., Rachmadtullah, R., Samsudin, A., Syaodih, E., Nurtanto, M., \& Tambunan, A. R. S. (2020). The perceptions of primary school teachers of online learning during the covid-19 pandemic period: A case study in Indonesia. Journal of Ethnic and Cultural Studies, 7(2), 90-109. https://doi.org/10.29333/ ejecs/388

Reska, E. K. (2015). Teaching Elementary Age Youth Catching Skills Using Theoretically Based Motor Development Strategies. University of West Florida.

Robinson, L. E., Webster, E. K., Logan, S. W., Lucas, W. A., \& Barber, L. T. (2012). Teaching Practices that Promote Motor Skills in Early Childhood Settings. Early Childhood Education Journal, 40(2), 79-86. https://doi.org/10.1007/s10643-011-0496-3

Sezici, E., \& Akkaya, D. D. (2020). The effect of preschool children's motor skills on self-care skills. Early Child Development and Care, 190(6), 963-970. https://doi.org/10.1080/03004430.2020.1737040

Sigmundsson, H., \& Haga, M. (2016). Motor competence is associated with physical fitness in four- to six-year-old preschool children. European Early Childhood Education Research Journal, 24(3), 477-488. https:/ / doi.org/10.1080/1350293X.2016.1164411

Suggate, S., Stoeger, H., \& Pufke, E. (2017). Relations between playing activities and fine motor development. Early Child Development and Care, 187(8), 1297-1310. https://doi.org/10.1080/03004430.2016.1167047

Szente, J. (2020). Live Virtual Sessions with Toddlers and Preschoolers amid COVID-19: Implications for Early Childhood Teacher Education. Journal of Technology and Teacher Education, 28(2), 373-380.

Tandon, P., Hassairi, N., Soderberg, J., \& Joseph, G. (2020). The relationship of gross motor and physical activity environments in child care settings with early learning outcomes. Early Child Development and Care, 190(4), 570-579. 
https:/ / doi.org/10.1080/03004430.2018.1485670

Temple, V. A., Crane, J. R., Brown, A., Williams, B. L., \& Bell, R. I. (2016). Recreational activities and motor skills of children in kindergarten. Physical Education and Sport Pedagogy, 21(3), 268-280. https:/ / doi.org/10.1080/17408989.2014.924494

Wainwright, N., Goodway, J., John, A., Thomas, K., Piper, K., Williams, K., \& Gardener, D. (2020). Developing children's motor skills in the Foundation Phase in Wales to support

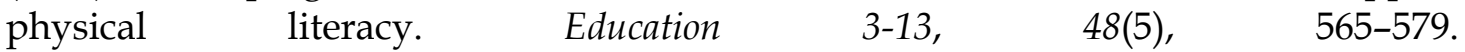
https:/ / doi.org/10.1080/03004279.2019.1633374

Wulandari, H., \& Purwanta, E. (2020). Pencapaian Perkembangan Anak Usia Dini di Taman Kanak-kanak selama Pembelajaran Daring di Masa Pandemi Covid-19. Jurnal Obsesi : Jurnal Pendidikan Anak Usia Dini, 5(1), 452. https:/ / doi.org/10.31004/obsesi.v5i1.626

Yao Jijun, C. X. (2020). What Role Should Teachers Play in Online Teaching during the COVID19 Pandemic? Evidence from China. Science Insights Education Frontiers, 5(2), 517-524. https:/ / doi.org/10.15354/sief.20.ar035

Zhang, C., \& Quinn, M. F. (2018). Promoting Early Writing Skills through Morning Meeting Routines: Guidelines for Best Practices. Early Childhood Education Journal, 46(5), 547556. https://doi.org/10.1007/s10643-017-0886-2

Zhang, L., Sun, J., Richards, B., Davidson, K., \& Rao, N. (2018). Motor Skills and Executive Function Contribute to Early Achievement in East Asia and the Pacific. Early Education and Development, 29(8), 1061-1080. https://doi.org/10.1080/10409289.2018.1510204 